\title{
Brazilian Journal of Chemical

\section{PREPARING AGRICULTURAL RESIDUE BASED ADSORBENTS FOR REMOVAL OF DYES FROM EFFLUENTS - A REVIEW}

\author{
D. S. Kharat \\ Central Pollution Control Board, East Arjun Nagar, Delhi-110032, India. \\ Phone: + (91) (11) 43102443, Fax: + (91) (11) 22301955 \\ E-mail: kharatds@hotmail.com \\ (Submitted: October 9, 2013 ; Accepted: February 11, 2014)
}

\begin{abstract}
Industries engaged in dyeing operation generate coloured effluent due to the presence of spent dyes. Adsorption is among the various treatment processes employed for removal of dyes from effluents. Activated carbon is mostly used as an adsorbent in the treatment process. Attempts have been made by researchers to use non-conventional, low-cost, naturally-occurring biomass as adsorbents, including fruit peals, seeds, leaves, bark, sawdust, straw, ash, sludge and others that are abundantly available. The literature indicates that the dye adsorption capacities of these non-conventional biomasses largely depend on the methods of processing and the types of dyes. This review highlights methods used to prepare the adsorbents, along with their adsorption capacity for removal of different dyes from effluents.

Keywords: Adsorption; Dye removal; Agricultural residue; Low-cost adsorbent.
\end{abstract}

\section{INTRODUCTION}

Annual production of dyes is to the tune of $7 \times 10^{5}$ tonnes worldwide (Allen and Koumanova, 2005). Dyes produced are classified as acid dyes, basic dyes, direct dyes, disperse dyes, reactive dyes and sulfur dyes according to their chemical constituents and application (Zollinger, 1991). Textile dyeing industries, pulp and paper industries and tanneries are the main consumers of dyes and are also responsible for discharge of voluminous coloured effluents. About 10 to $15 \%$ of the dyes consumed in the dyeing processes are disposed in the effluent (USEPA, 1997). In order to address the colour problems, industries are using various treatment processes including adsorption. Activated carbon is the most used adsorbent in adsorption columns. There have been attempts by researchers to explore the adsorption potential of non-conventional, naturally-occurring agricultural residues in dye removal from effluents. In India alone more than 400 million tonnes of agricultural residue is generated annually (Raghuvanshi et al., 2004), which includes rice husk, bagasse, stalk, coir pith etc. Exploring application of the agricultural residues for use as adsorbents can provide suitable alternatives for the removal of spent dyes from industrial effluents.

\section{REVIEW OF ADSORBENTS}

\section{Fruit Peels}

Babu et al. (2011) prepared three activated carbons from fruit peels, namely Citrus documana (NCDC), Citrus medica (NCMC) and Citrus aurantifolia (NCAC). The peels were dried, crushed and washed. After drying, the peels were carbonized at $500{ }^{\circ} \mathrm{C}$ in a nitrogen flow and subjected to oxidation with $1 \mathrm{~N} \mathrm{HNO}_{3}$ solution. These carbons were washed

*To whom correspondence should be addressed 
to remove acid and dried at $150{ }^{\circ} \mathrm{C}$ for use as adsorbents for removal of Reactive red 2 dye from effluent. The study reported the adsorption capacities of NCDC, NCMC and NCAC as $0.608 \mathrm{mg} / \mathrm{g}, 0.580 \mathrm{mg} / \mathrm{g}$ and $0.566 \mathrm{mg} / \mathrm{g}$ respectively at an initial dye concentration of $20 \mathrm{mg} / \mathrm{g}$ and adsorbent dose of $30 \mathrm{~g} / \mathrm{L}$. the adsorption potential of mosambi peel was studied by Ladhe et al. (2011) using Erichrome black T dye as adsorbate. The adsorbent was cleaned, ground to obtain powder (180-300 $\mu \mathrm{m})$ and dried. Then the powder was treated with concentrated sulfuric acid in a weight ratio of 1:1 for 24 hours, followed by washing with $\mathrm{NaHCO}_{3}$ solution and distilled water and drying. They observed Erichrome black $\mathrm{T}$ dye removal efficiency was $90 \%$ at a dye concentration of $50 \mathrm{mg} / \mathrm{L}$ and adsorbent dose of $0.004 \mathrm{~g} / \mathrm{cc}$. Parvathi and Maruthavanan (2010) performed adsorption studies using tapioca peel for removal of Megeta MB dye. They found that higher percentage removals were observed at solution $\mathrm{pH} 7$ and the equilibrium was reached within 120 minutes of contact time. Jackfruit peel $(0.84 \mathrm{~mm}$ in size) was used as adsorbent by Jayarajan et al. (2011) to remove Rhodamine dye. They reported a maximum colour removal of $25.3 \%$ at an adsorbent dose of $3.0 \mathrm{~g} / \mathrm{L}$ and dye concentration of $100 \mathrm{mg} / \mathrm{L}$. In a study by Velmurugan et al. (2011), orange peel, neem leaves and banana peel were dried at $105{ }^{\circ} \mathrm{C}$ for 48 hours and ground to powder (600 $\mu \mathrm{m}$ particle size). The study reported that the adsorption capacities of orange peel for different dyes were in the order of Methyl orange $>$ Methylene blue $>$ Rhodamine $\mathrm{B}>$ Congo red $>$ Methylene violet $>$ Amido black 10B. An orange peel (Citrus sinensis L.) based adsorbent was also prepared and employed for the removal of Remazol brilliant blue dye from synthetic dye effluent by Mafra et al. (2013). They found that the equilibrium was reached in 15 hours of contact time with dye concentration $30-250 \mathrm{mg} / \mathrm{L}$. The adsorption capacity of the orange peel adsorbent decreased with increase in temperature. The equilibrium data were reasonably described by the Langmuir and Freundlich isotherms. The authors reported that the adsorption capacities of orange peel adsorbent were $11.62 \mathrm{mg} / \mathrm{g}$, $10.70 \mathrm{mg} / \mathrm{g}, 8.61 \mathrm{mg} / \mathrm{g}, 6.39 \mathrm{mg} / \mathrm{g}$ and $5.54 \mathrm{mg} / \mathrm{g}$ at $20{ }^{\circ} \mathrm{C}, 30{ }^{\circ} \mathrm{C}, 40{ }^{\circ} \mathrm{C}, 50{ }^{\circ} \mathrm{C}$ and $60{ }^{\circ} \mathrm{C}$, respectively. In another study, grape juice waste was used by Ansari et al. (2011) to evaluate adsorption of Methylene blue dye from aqueous solution. They reported that maximum adsorption of Methylene blue dye was achieved at pH 10. Ong et al. (2010) studied adsorption of Methylene blue dye in a packed bed of durian peel powder ( $1 \mathrm{~mm}$ sieve size). The study established that durian peel is a potentially useful and attractive adsorbent for removed of Methylene blue from aqueous solution. They reported that a flow rate of $15 \mathrm{~mL} / \mathrm{min}$ showed an early breakthrough time.

\section{Sugarcane Bagasse}

Azhar et al. (2005) studied the removal of Methyl red dye using treated sugarcane bagasse and compared the results with those obtained using powered activated carbon. As per the study, one portion of ground bagasse with particle size between -80 to +230 mesh was treated with $1 \%$ formaldehyde in $\mathrm{w} / \mathrm{v}$ ration of $1: 5$ at $50{ }^{\circ} \mathrm{C}$ for 4 hours followed by activation at $80^{\circ} \mathrm{C}$ for 24 hours. The other portion of the bagasse was treated with sulfuric acid and heated in a muffle furnace for 24 hours at $150{ }^{\circ} \mathrm{C}$, followed by soaking in $1 \%$ sodium bicarbonate solution overnight. The study reported adsorption efficiencies of the different adsorbents in the order of powdered activated carbon $>$ bagasse treated with formaldehyde $>$ bagasse treated with sulfuric acid. Untreated, formaldehyde-treated and sulfuric acid-treated sugarcane bagasse powders were used by Abdullah et al. (2005) for removal of Ethylene red dye from aqueous solution. The method of preparing formaldehyde-treated bagasse powder and sulfuric acidtreated sugarcane bagasse powder remained the same as that used by Azhar et al. (2005). The results reported indicated that sulfuric acid-treated sugarcane bagasse gave better performance as compared to the formaldehyde-treated sugarcane bagasse. Amin (2008) studied the removal of Reactive orange dye from aqueous solutions by activated carbons prepared from sugarcane bagasse. The bagasse powder was sieved to an average size of $0.05 \mathrm{~mm}$. One portion of bagasse was carbonized in the absence of oxygen at $600{ }^{\circ} \mathrm{C}$ for 1 hour. The second portion of bagasse powder was soaked in $\mathrm{ZnCl}_{2}$ solution $(50 \%$ concentration) and the third portion of bagasse powder in $\mathrm{H}_{3} \mathrm{PO}_{4}$ solution (28\% concentration) for 24 hours. After decantation, the samples were pyrolyzed in a muffle furnace in the absence of air at $600{ }^{\circ} \mathrm{C}$ for 1 hour. The study reported that the adsorption capacities of physically carbonized, $\mathrm{ZnCl}_{2}$-treated and $\mathrm{H}_{3} \mathrm{PO}_{4}$-treated bagasse powder samples were observed as $3.48 \mathrm{mg} / \mathrm{g}, 2.83 \mathrm{mg} / \mathrm{g}$ and $1.8 \mathrm{mg} / \mathrm{g}$, respectively.

Adsorption studies were carried out using bagasse fly ash as an adsorbent and reactive dyes as adsorbate by Rachakornkij et al. (2004). The fly ash collected from a sugar mill was dried at $110{ }^{\circ} \mathrm{C}$ and sieved through a sieve size of $150 \mu \mathrm{m}$. The study reported monolayer adsorption capacity of $16.42 \mathrm{mg} / \mathrm{g}$, $32.468 \mathrm{mg} / \mathrm{g}$ and $18.282 \mathrm{mg} / \mathrm{g}$ with Remazol Black B 
dye, Remazol brilliant blue $\mathrm{R}$ dye and Remazol brilliant red dye, respectively. Reghuvanshi et al. (2004) treated sugarcane bagasse with concentrated sulfuric acid at $150-160{ }^{\circ} \mathrm{C}$ for 36 hours. The carbonized material so obtained was washed, dried and ground to $0.33 \mathrm{~mm}$ size. The processed bagasse and raw bagasse were used as adsorbents for the removal of Methylene blue from solution. The average percentage of dye removal with processed bagasse was found to be $18 \%$ more than that obtained with raw bagasse. The work done by Wong et al. (2009) with natural and quartenary ammonium chloride treated sugarcane bagasse shown that the optimum $\mathrm{pH}$ for the removal of Basic blue 3 dye and Reactive orange 16 dye is between 6 to 8 . For their study, quartenisation of bagasse was carried out by soaking in $\mathrm{NaOH}$ solution for 30 minutes. The adsorbent was then mixed with quartenary ammonium chloride $(65 \% \mathrm{w} / \mathrm{w})$ in water. The mixture was heated at $60-$ $70{ }^{\circ} \mathrm{C}$ for 4 hours. It was then rinsed with distilled water and suspended in dilute $\mathrm{HCl}$ solution at $\mathrm{pH} 3$ for 30 minutes. Then the adsorbent was washed with distilled water and dried at $50{ }^{\circ} \mathrm{C}$ in an oven overnight for use as modified adsorbent. The maximum adsorption capacities were reported as $37.59 \mathrm{mg} / \mathrm{g}$ and $34.48 \mathrm{mg} / \mathrm{g}$ for Basic blue 3 dye and Reactive orange 16 dye, respectively.

Ho et al. (2005) studied adsorption of three dyes, namely Basic violet 10, Basic violet 1 and Basic green 4 , from aqueous solution onto sugarcane dust (particle size 351-589 $\mu \mathrm{m}$ ). The Langmuir monolayer equilibrium capacities for these dyes were $50.4 \mathrm{mg} / \mathrm{g}$, $20.6 \mathrm{mg} / \mathrm{g}$ and $13.9 \mathrm{mg} / \mathrm{g}$ for Basic violet 1, Basic green 4 and Basic violet 10, respectively. Bagasse ash has been used as a low cost adsorbent by Khandelwal and Gaikwad (2011) for investigating removal of Orange II dye. They reported that the percent adsorption of dye increased with decreasing flow rate from $2 \mathrm{~L} /$ hour to $1 \mathrm{~L} /$ hour, by increasing bed height from $15 \mathrm{~cm}$ to $45 \mathrm{~cm}$, by decreasing the initial dye concentration from $150 \mathrm{mg} / \mathrm{L}$ to $100 \mathrm{mg} / \mathrm{L}$ and by increasing the column diameter from $2.54 \mathrm{~cm}$ to $3.50 \mathrm{~cm}$. Kausik et al. (2008) used powdered sugarcane bagasse, coconut coir pith, cow dung and eucalyptus bark treated with $20 \%$ sodium hydroxide solution. The adsorbents were aminated with a mixture of $10 \%$ amine and water at $70{ }^{\circ} \mathrm{C}$ and finally treated with acid for protonation. The adsorbents were used for treating Reactive blue 171, Reactive yellow 84 and Reactive red 141 dyes. The study reported that, among the above four adsorbents, bagasse had a slightly higher efficiency with $20-26 \%$ dye removal.

In another study, Ashoka and Inamdar (2010) used formaldehyde-treated bagasse and acid-treated bagasse for adsorption of Methyl red dye. The bagasse powder $(0.1456 \mathrm{~mm}$ particle size $)$ was reacted with $1 \%$ formaldehyde (w/v ratio of $1: 5)$ at $50{ }^{\circ} \mathrm{C}$ for 4 hours followed by washing and drying at $80^{\circ} \mathrm{C}$. Acid treatment involved treating bagasse with sulfuric acid (in the ratio of 1:1) and then heating in a muffle furnace for 24 hours at $150{ }^{\circ} \mathrm{C}$ and soaking in sodium bicarbonate solution overnight to remove acid, followed by washing and drying at $150{ }^{\circ} \mathrm{C}$ for 24 hours. As per the study, the dye removal efficiency of acid-treated bagasse was higher than that of formaldehyde-treated bagasse. Using a similar treatment method for bagasse, Mahesh et al. (2010) observed that the Crystal violet dye removal efficiency of formaldehyde-treated bagasse was more than that of acid-treated bagasse.

\section{Husk}

Ong et al. (2007) ground rice hull to pass through a $1 \mathrm{~mm}$ sieve and used it as natural rice hull (NRH). Ethylenediamine (EDA) modified rice hull was also prepared by treating natural rice hull with ethylenediamine in a ratio of $1.0 \mathrm{~g}$ rice hull to 0.02 mole of EDA in a well-stirred water bath at $80{ }^{\circ} \mathrm{C}$ for 2 hours to enable it to function as a sorbent for removal of Basic blue 3 and Reactive orange 16 dyes. They observed adsorption capacities, calculated from the Langmuir isotherm, of $14.68 \mathrm{mg} / \mathrm{g}$ and $6.24 \mathrm{mg} / \mathrm{g}$ for Basic blue 3 dye and Reactive orange 16 dye respectively. Sharma and Janveja (2008) conducted a study on the removal of Congo red dye from the effluent of a textile industry using rice husk carbon activated by steam. The study reported that a dose of $0.08 \mathrm{~g} / \mathrm{L}$ of rice husk carbon removed 10 to $99 \%$ of dye from aqueous solution with an initial dye concentration of $25 \mathrm{ppm}$ within contact times from 20 to 200 minutes.

\section{Sawdust}

Experiments for removal of Ethylene blue dye using saw dust $(420-85 \mu \mathrm{m})$ were performed by Gong et al. (2008). The activation process included treating sawdust with $240 \mathrm{~mL}$ of dioxane, $24 \mathrm{~mL}$ of $20 \%$ $\mathrm{NaOH}$ and $40 \mathrm{ml}$ of epichlorohydrin for 5 hours at $65{ }^{\circ} \mathrm{C}$. The reaction product was filtered, washed and dried. They observed Langmuir adsorption capacities of untreated and treated sawdust as $87.7 \mathrm{mg} / \mathrm{g}$ and $188.7 \mathrm{mg} / \mathrm{g}$, respectively. Beach wood sawdust was used as an adsorbent by Izadyar and Rahimi (2007) to treat Direct orange 26, Acid orange 7 and Acid green 20 dyes. The adsorbent with a sawdust particle size of $150-250 \mu \mathrm{m}$ had monolayer adsorption ca- 
pacity of $2.78 \mathrm{mg} / \mathrm{g}, 5.06 \mathrm{mg} / \mathrm{g}$ and $7.81 \mathrm{mg} / \mathrm{g}$ for Direct orange 26 dye, Acid orange 7 dye and Acid green 20 dye, respectively. El-latif et al. (2010) performed a study of removal of Methylene blue dye using oak sawdust. The sawdust was treated with $0.1 \mathrm{~N} \mathrm{NaOH}$ solution and immobilized on alginate biopolymer for use as an adsorbent. The study revealed an adsorption capacity of sawdust of 38.46 $\mathrm{mg} / \mathrm{g}$. The kinetics followed closely a Pseudo-second order model.

\section{Sludge}

Activated sludge was dried at $105{ }^{\circ} \mathrm{C}$ to a constant weight and sieved to $<205 \mu \mathrm{m}$ for use as an adsorbent in a study for removal of Rhodamine-B dye $(\mathrm{Ju}$ et al., 2006). The results indicated that the adsorption capacity of activated sludge increased with decreasing initial $\mathrm{pH}$ and temperature. The Langmuir monolayer adsorption capacities were $5.121 \mathrm{mg} / \mathrm{g}$, $4.847 \mathrm{mg} / \mathrm{g}, 4.456 \mathrm{mg} / \mathrm{g}$ and $3.725 \mathrm{mg} / \mathrm{g}$ at temperature of $5{ }^{\circ} \mathrm{C}, 15^{\circ} \mathrm{C}, 25^{\circ} \mathrm{C}$, and $45^{\circ} \mathrm{C}$, respectively. Reddy et al. (2006) conducted a study of reactive dye removal from dyeing unit effluent using sewage sludge-derived activated carbons by pyrolysis. The pyrolysis was carried out in a muffle furnace in the absence of oxygen. Subsequently, $10 \mathrm{~g}$ of pyrolysed sludge was impregnated into $25 \mathrm{~mL}$ of activating agent ( $3 \mathrm{M} \mathrm{ZnCl}_{2}$ solution) for 24 hours at room temperature, followed by washing with distilled water and drying at $105{ }^{\circ} \mathrm{C}$ for 24 hours. The Langmuir monolayer adsorption capacity of the sludge-derived carbon was $33.5 \mathrm{mg} / \mathrm{g}$. The adsorption potential of granular sludge (from a pilot scale reactor treating waste water) with Acid orange 7 dye was investigated by Mendez-Paz et al. (2005). A dye removal efficiency of $92 \%$ was achieved in continuous treatment mode with dye loading rate of $590 \mathrm{mg} / \mathrm{L}$.day. Won et al. (2006) studied the adsorption potential of protonated fermentation waste (Corynebacterium glutamicum) with Reactive black 5 dye. For that study, the protonated biomass was prepared by treating the biomass with $1 \mathrm{~N} \mathrm{HNO}_{3}$ solution, followed by washing with deionized distilled water and drying. They observed that, in the range of $\mathrm{pH} 1$ to 3 , removal of dye was $100 \%$. The maximum dye uptakes using the Langmuir isotherm were $169.5 \mathrm{mg} / \mathrm{g}$ and $185.2 \mathrm{mg} / \mathrm{L}$ at $20{ }^{\circ} \mathrm{C}$ and $40{ }^{\circ} \mathrm{C}$, respectively. The study further showed that the uptake of dye was not significantly affected by the concentration of salt in solution. Won et al. (2006a) studied different sludges from a water treatment plant, sewage treatment plant, anaerobic digestion and land fill for the removal of Reactive orange 16 dye. The sludges were treated with $1 \mathrm{M} \mathrm{HNO}_{3}$ solution for 24 hours and dried at $60{ }^{\circ} \mathrm{C}$ to use these sludges as adsorbents. The maximum adsorption capacities using the Langmuir equation were $159.0 \mathrm{mg} / \mathrm{g}, 114.7 \mathrm{mg} / \mathrm{g}$, $86.8 \mathrm{mg} / \mathrm{g} 47.0 \mathrm{mg} / \mathrm{g}$ for land fill sludge, sewage sludge, anaerobic sludge and water treatment plant sludge, respectively at $\mathrm{pH} 2$.

\section{Organisms}

Kim et al. (2004) studied the adsorption of Reactive orange 16 dye using dead cell of brewery yeast. The yeast was washed with deionized water and dried at $80^{\circ} \mathrm{C}$. The dried biomass was ground to an average size of $112.5 \mu \mathrm{m}$. An adsorption capacity of $0.604 \mathrm{mg} / \mathrm{g}, 0.090 \mathrm{mg} / \mathrm{g}$ and $0.50 \mathrm{mg} / \mathrm{g}$ were observed at solution pHs of 3, 7 and 10, respectively. Studies were conducted by Singh and Rastogi (2004) using baker's yeast cells as an adsorbent for adsorption of various dyes. For preparation of the adsorbent, baker's yeast $(2 \mathrm{~g})$ was suspended in saline $(6 \mathrm{~mL})$. The yeast was re-suspended in $6 \mathrm{ml}$ of $0.1 \mathrm{M}$ Acetate buffer with $\mathrm{pH}$ 4.6. The sediment was further suspended in acetate buffer to obtain a ca. 33\% yeast suspension $(\mathrm{v} / \mathrm{v})$. Then $3 \mathrm{~mL}$ of yeast suspension was added to $1 \mathrm{~mL}$ of ferrofluid, and incubated at room temperature for 1 hour. After this treatment, the majority of the yeast cells were modified. The modified yeast cells were heated in boiling water and then washed with saline and stored at $4{ }^{\circ} \mathrm{C}$ for use as adsorbent. The study reported that the adsorption capacities for Acridine orange dye, Aniline blue dye, Crystal violet dye, Malachite green dye and Safranine $\mathrm{O}$ dye were $82.8 \mathrm{mg} / \mathrm{g}, 430.2 \mathrm{mg} / \mathrm{g} 85.9 \mathrm{mg} / \mathrm{g}$, $19.6 \mathrm{mg} / \mathrm{g}$ and $90.3 \mathrm{mg} / \mathrm{g}$, respectively. The decolourization potential of fungus was performed by Akar et al. (2009) using Reactive red 198 dye. A maximum dye adsorption capacity of $1.03 \times 10^{-4} \mathrm{~mol} / \mathrm{g}$ was observed at $\mathrm{pH} 2$ and adsorbent dose of $2.0 \mathrm{~g} / \mathrm{L}$. They observed an increase in the adsorption capacity with temperature, indicating that the adsorption process is endothermic. Fu and Viraghavan (2003) studied the dye removal potential of immobilized fungal biomass (Aspergillus niger) with four dyes, namely Acid blue 29, Basic blue 9, Congo red and Disperse red 1. The adsorption capacities observed were 64.7 $\mathrm{mg} / \mathrm{g}$ for Acid blue $29 \mathrm{dye}, 8.9 \mathrm{mg} / \mathrm{g}$ for Basic blue 9 dye, $1.1 \mathrm{mg} / \mathrm{g}$ for Congo red dye and $0.1 \mathrm{mg} / \mathrm{g}$ for Disperse red 1 dye.

\section{Grains}

Jaikumar and Ramamurthi (2009) studied the adsorption of Acid yellow 17 dye by an adsorbent 
prepared from spent brewery grains. The spent brewery grains were suspended in $0.13 \mathrm{M}$ sulphuric acid solution (20 g of grain per $100 \mathrm{~mL}$ of solution) for one hour. The grains were washed, dried and ground for use as adsorbent. They observed the highest adsorption capacity at $\mathrm{pH} 2$ with an initial dye concentration of $150 \mathrm{mg} / \mathrm{L}$, dose of adsorbent $0.5 \mathrm{~g} / \mathrm{L}$ and contact time of 40 minutes.

\section{Coconut}

Theivarasu and Mylsamy (2010) conducted an adsorption study of Rhodamine-B dye on char prepared by treating the coconut shell with concentrated sulfuric acid at ratio of $1: 1(\mathrm{w} / \mathrm{v})$. The activation was performed by heating in a muffle furnace at $550{ }^{\circ} \mathrm{C}$ for 7 hours, followed by washing and drying. The adsorption capacity of the treated coconut shell char was reported as $41.67 \mathrm{mg} / \mathrm{g}$. For removal of Coomassie brilliant blue dye on coir pith as adsorbent, Prasad et al. (2008) conducted studies including the effects of time, initial dye concentration and dose of adsorbent. Treatment of coir pith includes dipping the coir pith in a one molar solution of $\mathrm{HCl}$, washing with distilled water and drying in an oven at $55^{\circ} \mathrm{C}$. The study reported a maximum adsorption capacity of $31.84 \mathrm{mg} / \mathrm{g}$ and the adsorption capacity for the system was $6.43 \mathrm{mg} / \mathrm{g}$.

\section{Palm Shell}

Rajavel et al. (2003) evaluated the removal efficiency of Dark green PLS dye from textile industry wastewater using carbons prepared from palm nut shell, cashew nut shell and broom stick. The carbons were prepared by treating 4 parts of each material with 2 parts of concentrated sulfuric acid and heating at $140-170{ }^{\circ} \mathrm{C}$ for 24 hours. The resultant materials were filtered, washed with water, dried at $105-110^{\circ} \mathrm{C}$ and sieved to an average particle diameter of $0.5 \mathrm{~mm}$ for use as adsorbents. The adsorption capacities of palm nut shell carbon, cashew nut shell carbon and broom stick carbon were reported as $0.84 \mathrm{mg} / \mathrm{g}$, $1 \mathrm{mg} / \mathrm{g}$ and $0.63 \mathrm{mg} / \mathrm{g}$, respectively. The adsorption study by Rusly and Ibrahim (2010) involved palm shell activated carbon and Reactive red 3 BS dye. They observed that, upon increasing adsorbent dose and agitation, the efficiency of dye removal increased. The study reported that, at the optimal condition, the dye removal efficiency reached more than $90 \%$ and the adsorption capacity was more than $7 \mathrm{mg} / \mathrm{g}$. Batch adsorption experiments were carried out by Sreelatha and Padmaja (2008) for removal of Methylene blue and Rhodamine 6G dyes from solu- tion using palm shell powder. The sorption capacity was dependent on the operating parameters and the process was $\mathrm{pH}$ dependent above $\mathrm{pH}$ 4.0. The adsorption capacities were reported to be $121.5 \mathrm{mg} / \mathrm{g}$ and $105 \mathrm{mg} / \mathrm{g}$ for Methylene blue dye and Rhodomine $6 \mathrm{G}$ dye, respectively.

\section{Leaves}

Gulmohor leaves were ground, washed and dried to use as adsorbent in an adsorption study by Ponnusami et al. (2009). The results indicated that the equilibrium dye removal capacity of gulmohar leaves with Methylene blue dye varies from $132.40 \mathrm{mg} / \mathrm{g}$ to $34.76 \mathrm{mg} / \mathrm{g}$ with adsorbent dose of $0.5 \mathrm{~g}$ to $2.5 \mathrm{~g} / \mathrm{L}$ and a dye concentration of $100 \mathrm{mg} / \mathrm{l}$. The monolayer adsorption capacities of gulmohar leaf powder were observed $120 \mathrm{mg} / \mathrm{g}, 178 \mathrm{mg} / \mathrm{g}$ and $253 \mathrm{mg} / \mathrm{g}$ at temperature of $293 \mathrm{~K}, 303 \mathrm{~K}$ and $313 \mathrm{~K}$, respectively. Singh and Rastogi (2004) used tea leaves as adsorbent for removal of Malachite green and Methylene blue dyes. The dried leaf powder was impregnated with $\mathrm{H}_{3} \mathrm{PO}_{4}(50 \% \mathrm{w} / \mathrm{v})$ in the ratio of $2: 1(\mathrm{w} / \mathrm{v})$ and carbonized at $300{ }^{\circ} \mathrm{C}$. The carbons were washed and dried at $100{ }^{\circ} \mathrm{C}$ and sieved to $170-200$ mesh size. The adsorption data fitted well the Langmuir isotherm with monolayer adsorption capacities of $444.44 \mathrm{mg} / \mathrm{g}$ and $454.5 \mathrm{mg} / \mathrm{g}$ for Malachite green dye and Methylene blue dye, respectively at $25{ }^{\circ} \mathrm{C}$. The column study indicated break through capacities of $300 \mathrm{mg} / \mathrm{g}$ and $275 \mathrm{mg} / \mathrm{g}$ for Malachite green dye and Methylene blue dye respectively. Hamissa et al. (2008) conducted a study on adsorptive removal of Alpacide yellow dye from aqueous solution on fibres extracted from agave leaves. The agave leaves were subjected to a salt hydrolysis at $80{ }^{\circ} \mathrm{C}$ for 8 hours. The extracted fibres were washed to remove the parenchyma and cut to $4 \mathrm{~cm}$ size and dried at $70{ }^{\circ} \mathrm{C}$ for use as adsorbent. They observed maximum adsorption capacity of agave leaves of $16.97 \mathrm{mg} / \mathrm{g}, 15.79 \mathrm{mg} / \mathrm{g}$ and $21.41 \mathrm{mg} / \mathrm{g}$ at $20{ }^{\circ} \mathrm{C}, 30{ }^{\circ} \mathrm{C}$ and $50{ }^{\circ} \mathrm{C}$, respectively. Neem (Azadirachta indica) leaf powder was used for treatment of Fast green dye (C.I. 42053) in a study conducted by Tahir et al. (2008). The neem leaves were powdered and washed with distilled water and then dried at $60{ }^{\circ} \mathrm{C}$ for use as an adsorbent. The study indicated that the maximum adsorption capacity was $92.6 \%$ with $1 \mathrm{~g} / 30 \mathrm{~mL}$ of adsorbent dose and $5 \times 10^{-4} \mathrm{~mol} / \mathrm{dm}^{3}$ strength solution of Fast green dye. Hema and Arivoli (2007) studied adsorption of dyes onto acid activated pandanus leaves. The activation method involved carbonization with concentrated sulfuric acid in a ratio of $1: 1(\mathrm{w} / \mathrm{v})$ with heating at $400{ }^{\circ} \mathrm{C}$ for 12 hours in a 
furnace. The resulting carbon was washed with distilled water and then dried at $100{ }^{\circ} \mathrm{C}$ for 4 hours for use as adsorbent. The adsorption capacities were $21.491 \mathrm{mg} / \mathrm{g}, 20.267 \mathrm{mg} / \mathrm{g}, 20.069 \mathrm{mg} / \mathrm{g}$ and $18.928 \mathrm{mg} / \mathrm{g}$ at $30{ }^{\circ} \mathrm{C}, 40{ }^{\circ} \mathrm{C}, 50{ }^{\circ} \mathrm{C}$ and $60{ }^{\circ} \mathrm{C}$, respectively in the case of Congo red dye. With Malachite green dye, the observed adsorption capacities were $9.737 \mathrm{mg} / \mathrm{g}, 9.624 \mathrm{mg} / \mathrm{g} 9.633 \mathrm{mg} / \mathrm{g}$ and 9.569 $\mathrm{mg} / \mathrm{g}$ at $30^{\circ} \mathrm{C}, 40^{\circ} \mathrm{C}, 50^{\circ} \mathrm{C}$ and $60{ }^{\circ} \mathrm{C}$, respectively.

Waste tendu (Diospyros melanoxylon) leaf cuttings were processed and used as an adsorbent for removal of Crystal violet dye by Nanda and Ghole (2008). Tendu leaf cuttings were powdered and sieved with 80 mesh (called TLR). Carbons were prepared by treating 5 parts of TLR with 3 parts of concentrated sulfuric acid at $120-130{ }^{\circ} \mathrm{C}$ for 24 hours. The carbonized mass was freed from acid by soaking in $1 \%$ solution of sodium bicarbonate, followed by drying and sieving through 80 mesh sieve for use as adsorbent (called TLR-CM). One portion of LTR was treated with 5 parts of $2 \mathrm{~N}$ sulfuric acid for 24 hours. Then the material was washed, dried, powdered and used as adsorbent (called TLR-2N). The study reported adsorption capacities of $67.57 \mathrm{mg} / \mathrm{g}$, $42.92 \mathrm{mg} / \mathrm{g}$ and $22.47 \mathrm{mg} / \mathrm{g}$ for TLR-2N, TLR and TLR-CM, respectively. El-Zawahry and Kamel (2004) used water hyacinths (Eichhornia crassipes) powder as adsorbent for removal of acid and reactive dyes from aqueous solution. The samples were cut to smaller size, air dried and ground and sieved to $0.147-1.5 \mathrm{~mm}$ size. The powder was subjected to a chemical scouring treatment (boiling with $20 \mathrm{~g} / \mathrm{L}$ sodium hydroxide for 2 hours at $120-130{ }^{\circ} \mathrm{C}$ in a 20:1 ratio). The material was filtered, washed and air dried for use as adsorbent. The study reported that the higher nitrogen percent of hyacinths showed higher adsorption capacities. Vijayaraghavan and Yun (2008) studied adsorption of Reactive black 5 dye using seaweed (Luminaries sp.). The adsorbent was ground to an average size of $0.4-0.6 \mathrm{~mm}$. Protonation of adsorbent involved treatment with $10 \mathrm{~g} / \mathrm{L}$ of $0.1 \mathrm{M}$ $\mathrm{HCl}$ solution followed by washing and drying. The maximum dye uptake of $101.5 \mathrm{mg} / \mathrm{g}$ was observed at $\mathrm{pH} 1.0$ and $40^{\circ} \mathrm{C}$.

Ncibi et al. (2007) studied adsorption of Reactive red 228 on sea grass leaf sheaths with variables including temperature, $\mathrm{pH}$ and chemical pre-treatment, and observed maximum colour removal at $\mathrm{pH}$ 5.0. Pre-treatment of the absorbent with phosphoric acid and nitric acid solution increased the adsorption efficiency up to $80 \%$. Aquatic plant (Hydrilla verticillata) biomass was experimented for removal of Malachite green dye from solution by Rajeshkannan et al. (2010) and the study showed an adsorption capacity of $91.97 \mathrm{mg} / \mathrm{g}$ at $\mathrm{pH}$ 8.0. Purai and Rattan (2009) used ash prepared from cow dung and commercial activated carbon. The ash was prepared in muffle furnaces at $500{ }^{\circ} \mathrm{C}$. The study revealed that $4.98 \mathrm{mg} / \mathrm{g}$ and $4.67 \mathrm{mg} / \mathrm{g}$ of dye were adsorbed dye adsorbed by cow dung ash and activated carbon, respectively, at $\mathrm{pH}$ 3.33. The authors noted that at $\mathrm{pH} 8.76$, the adsorption was the least for both the adsorbents.

\section{Tree Bark}

Patil et al. (2011) carried out adsorption studies of Methylene blue dye using teak tree bark with various process parameters. The maximum adsorption of Methylene blue dye was $333.33 \mathrm{mg} / \mathrm{g}$. The study revealed an increase in dye adsorption efficiency with increasing $\mathrm{pH}$, increasing temperature and decreased particle size of adsorbent.

\section{Straw}

Abdualhamid and Asil (2011) conducted adsorption studies for removal of Methylene blue dye using barley, wheat and oat straws as adsorbents. The straws were cut into pieces of $1 \mathrm{~cm}$ size, washed and dried at $65{ }^{\circ} \mathrm{C}$ overnight. One portion of each straw was subjected to soaking by immersing in water at room temperature for 20 days and then dried at $60{ }^{\circ} \mathrm{C}$ overnight for use as adsorbent. In the study, the maximum dye adsorption capacity for the straws before soaking followed the order: barley $>$ oat $>$ wheat, with values of $27.72 \mathrm{mg} / \mathrm{g}, 17.54 \mathrm{mg} / \mathrm{g}$ and $8.34 \mathrm{mg} / \mathrm{g}$, respectively. The maximum dye removal capacity of straws after soaking in water was found in the order of oat $>$ barley $>$ wheat, with values of $50.00 \mathrm{mg} / \mathrm{g}$, $22.22 \mathrm{mg} / \mathrm{g}$ and $11.11 \mathrm{mg} / \mathrm{g}$.

\section{Seeds}

Esterified natural papaya seeds were used by Nasuha et al. (2011) for adsorption of Methylene blue and Congo red dyes from effluent. Esterification was carried out by treating the adsorbent with methanol and $\mathrm{HCl}$ followed by washing and drying. Data for adsorption of Methylene blue dye fit well to the Langmuir isotherm and maximum adsorption capacities of $250.0 \mathrm{mg} / \mathrm{g}$ and $200 \mathrm{mg} / \mathrm{g}$ were observed for esterified adsorbent and natural adsorbent, respectively. Santhi et al. (2010) studied the adsorption potential of Annona squamosa seed with adsorbates, namely Methylene blue dye, Methylene red dye and Malachite green dye. Carbon was prepared by treating the mass with $\mathrm{H}_{2} \mathrm{SO}_{4}$ for 12 hours. After washing, the mass was treated with $2 \% \mathrm{NaHCO}_{3}$ 
solution to remove remaining acid, followed by drying and sieving to $125-250 \mu \mathrm{m}$ size. Dye adsorption capacities of $8.52 \mathrm{mg} / \mathrm{g}, 40.48 \mathrm{mg} / \mathrm{g}$ and $25.91 \mathrm{mg} / \mathrm{l}$ were observed for Methylene blue dye, Methylene red dye and Malachite green dye, respectively. Decolourization studies of Acid orange dye 7 by charcoal prepared from coffee grounds were performed by Nakamura et al. (2003). For preparing the adsorbent, extracted residues of coffee beans was dried to reduce the moisture content by $50 \%$ and the same was carbonized in a furnace at $800{ }^{\circ} \mathrm{C}, 1000{ }^{\circ} \mathrm{C}$ and $1200{ }^{\circ} \mathrm{C}$ and sieved through 10-20 mesh. The carbons were washed with distilled water and dried at $110{ }^{\circ} \mathrm{C}$ for use as adsorbents. The studies indicated that the equilibrium adsorption of Acid orange 7 dye was higher for charcoal carbonized at higher temperatures.

\section{Other Biomasses}

Habib et al. (2006) performed adsorption studies using tuberose sticks as adsorbent for removal of Methylene blue dye. The dried tuberose sticks were cut into small pieces, powdered and then sieved with a $425 \mu \mathrm{m}$ sieve for use as adsorbent. The maximum dye removal of $80 \%$ was achieved at $\mathrm{pH} 11$, adsorbent dose of $1 \mathrm{~g} / \mathrm{L}$ and dye concentration in solution of $40 \mathrm{mg} / \mathrm{L}$. In another study by Ramakrishna and Nagarajan (2009), flame tree (Delonix regia) pods were used for preparing adsorbents. The flame tree pods were crushed into smaller pieces and soaked with concentrated sulfuric acid in a 1:1 ratio (weight of material to volume of acid) for 48 hours and activated at $160{ }^{\circ} \mathrm{C}$ for 6 hours. The carbon so prepared was washed with distilled water and dried at $105^{\circ} \mathrm{C}$ for 2 hours to prepare the adsorbent. The data were reported to fit well to the Langmuir and Freundlich isotherms. The maximum adsorption capacity observed with Crystal violet dye was $16.70 \mathrm{mg} / \mathrm{g}$. A granule prepared from leaf, fruits and twigs of Muntingia calabura was utilized by Santhi et al. (2009) for adsorption of Methylene blue, Methylene red, and Malachite green dyes. The maximum adsorp- tion capacities were $20 \mathrm{mg} / \mathrm{g}, 58 \mathrm{mg} / \mathrm{g}$ and $32 \mathrm{mg} / \mathrm{g}$ for Methylene blue dye, Methylene red dye and Malachite green dye, respectively. Sivakumar and Palanisamy (2010) prepared an adsorbent by treating precursor wood with $\mathrm{H}_{3} \mathrm{PO}_{4}$ solution followed by activation at $800{ }^{\circ} \mathrm{C}$. The adsorbent so processed had a surface area of $918 \mathrm{~cm}^{2} / \mathrm{g}$. The adsorbent was used to remove Acid blue 92, Basic blue 29, Reactive red 4, and Direct blue 53 dyes from aqueous solution. Mittal et al. (2007) investigated the removal of Tartrazine dye by using hen feathers. To remove the adhering organic matter, feathers were treated with hydrogen peroxide followed by washing and drying. The study reported dye removal efficiencies of $47 \%, 52 \%$ and $55 \%$ at $30{ }^{\circ} \mathrm{C}, 40{ }^{\circ} \mathrm{C}$ and $50{ }^{\circ} \mathrm{C}$, respectively. Piccin et al. (2011) tested adsorption potential of chitosan for removal of commercial dye (FD\&C Red $n^{\circ} 40$ ) at different temperatures ( 298 to $338 \mathrm{~K}$ ). The maximum adsorption capacity of chitosan was observed as $1065.8 \mu \mathrm{mol} / \mathrm{g}, 1061.4 \mu \mathrm{mol} / \mathrm{g}, 800.8 \mu \mathrm{mol} / \mathrm{g}$, $508.5 \mu \mathrm{mol} / \mathrm{g}$ at $308 \mathrm{~K}, 318 \mathrm{~K}, 328 \mathrm{~K}$ and $338 \mathrm{~K}$, respectively. The authors observed that the adsorption process was exothermic in nature. Adsorption studies of Reactive red 120 and Reactive black 5 dyes onto cotton fibre were performed by Gamal et al. (2010). They observed the monolayer adsorption capacities of $11.63 \mathrm{mg} / \mathrm{g}$ and $6.22 \mathrm{mg} / \mathrm{g}$ for Reactive red 120 dye and Reactive black 5 dye, respectively. Schimmel et al. (2010) studied the adsorption potential of commercial activated carbon for Turquoise blue QG reactive bye. The adsorption studies were conducted to obtain isotherm and kinetic data under different experimental conditions. They observed maximum dye removal at a $\mathrm{pH}$ of 2 and temperature of $30^{\circ} \mathrm{C}$. The equilibrium data were reasonably described by the Langmuir and Freundlich isotherms. The authors reported that the adsorption capacity of activated carbon was $140.14 \mathrm{mg} / \mathrm{g}$. The kinetics followed closely a Pseudo-second order model. Table 1 show different agricultural residues used to prepare the adsorbents, along with adsorption capacities for removal of different dyes from effluents.

Table 1: Adsorption capacities of some agricultural residue based adsorbents for removal of different dyes from effluents.

\begin{tabular}{|l|l|l|l|}
\hline Name of Adsorbent & Dye & Adsorption Capacity & Reference \\
\hline Citrus documana & Reactive red 2 & $0.608 \mathrm{mg} / \mathrm{g}$ & Babu et al. $(2011)$ \\
\hline Citrus medica & Reactive red 2 & $0.580 \mathrm{mg} / \mathrm{g}$ & Babu et al. $(2011)$ \\
\hline Citrus aurantifolia & Reactive red 2 & $0.566 \mathrm{mg} / \mathrm{g}$ & Babu et al. $(2011)$ \\
\hline Orange peel (Citrus sinensis L.) & Remazol brilliant blue & $\begin{array}{l}11.62 \mathrm{mg} / \mathrm{g}\left(20^{\circ} \mathrm{C}\right), 10.70 \mathrm{mg} / \mathrm{g}\left(30^{\circ} \mathrm{C}\right), \\
8.61 \mathrm{mg} / \mathrm{g}\left(40{ }^{\circ} \mathrm{C}\right), 6.39 \mathrm{mg} / \mathrm{g} \\
\left(50{ }^{\circ} \mathrm{C}\right), 5.54 \mathrm{mg} / \mathrm{g}\left(60{ }^{\circ} \mathrm{C}\right) .\end{array}$ & \\
& & Mafra et.$(2013)$ \\
\hline
\end{tabular}


Continuation Table 1

\begin{tabular}{|c|c|c|c|}
\hline Name of Adsorbent & Dye & Adsorption Capacity & Reference \\
\hline Mosambi peel & Erichrome black T & $\begin{array}{l}90 \% \text { (Initial dye concentration } \\
50 \mathrm{mg} / \mathrm{L} \& \text { adsorbent dose } 4 \mathrm{~g} / \mathrm{L} \text { ) }\end{array}$ & Ladhe et al. (2011) \\
\hline Palm nut shell carbon & Dark green PLS & $0.84 \mathrm{mg} / \mathrm{g}$ & Rajavel et al. (2003) \\
\hline Cashew nut shell carbon & Dark green PLS & $1 \mathrm{mg} / \mathrm{g}$ & Rajavel et al. (2003) \\
\hline Broom stick carbon & Dark green PLS & $0.63 \mathrm{mg} / \mathrm{g}$ & Rajavel et al. (2003) \\
\hline Coconut shell char & Rhodamine-B & $41.67 \mathrm{mg} / \mathrm{g}$ & Theivarasu and Mylsamy (2010) \\
\hline Coir pith char & Coomassie brilliant & $31.84 \mathrm{mg} / \mathrm{g}$ & Prasad et al. (2008) \\
\hline Palm shell activated carbon & Reactive red $3 \mathrm{BS}$ & $7 \mathrm{mg} / \mathrm{g}$ & Rusly and Ibrahim (2010) \\
\hline \multirow[t]{2}{*}{ Palm shell powder } & \multirow{2}{*}{$\begin{array}{l}\text { Methylene blue } \\
\text { Rhodamine } 6 \mathrm{G}\end{array}$} & $121.5 \mathrm{mg} / \mathrm{g}$ & \multirow[t]{2}{*}{ Sreelatha and Padmaja (2008) } \\
\hline & & $105 \mathrm{mg} / \mathrm{g}$ & \\
\hline Sugarcane bagasse & Reactive orange & $3.48 \mathrm{mg} / \mathrm{g}$ & Amin (2008) \\
\hline Sugarcane bagasse $\left(\mathrm{ZnCl}_{2}\right.$ treated) & Reactive orange & $2.83 \mathrm{mg} / \mathrm{g}$ & $\operatorname{Amin}(2008)$ \\
\hline Sugarcane bagasse $\left(\mathrm{H}_{3} \mathrm{PO}_{4}\right.$ treated $)$ & Reactive orange & $1.8 \mathrm{mg} / \mathrm{g}$ & $\operatorname{Amin}(2008)$ \\
\hline Sugarcane bagasse fly ash & $\begin{array}{l}\text { Remazol Black B } \\
\text { Remazol brilliant blue R } \\
\text { Remazol Brilliant red }\end{array}$ & $\begin{array}{l}16.42 \mathrm{mg} / \mathrm{g} \\
32.468 \mathrm{mg} / \mathrm{g} \\
18.282 \mathrm{mg} / \mathrm{g}\end{array}$ & Rachakornkij et al. (2004) \\
\hline Sugarcane bagasse & $\begin{array}{l}\text { Basic blue } 3 \\
\text { Reactive orange } 16\end{array}$ & $\begin{array}{l}37.59 \mathrm{mg} / \mathrm{g} \\
34.48 \mathrm{mg} / \mathrm{g}\end{array}$ & Wong et al. (2009) \\
\hline Sugarcane dust & $\begin{array}{l}\text { Basic violet } 1 \\
\text { Basic violet } 10 \\
\text { Basic green } 4\end{array}$ & $\begin{array}{l}50.4 \mathrm{mg} / \mathrm{g} \\
13.9 \mathrm{mg} / \mathrm{g} \\
20.6 \mathrm{mg} / \mathrm{g}\end{array}$ & Ho et al. (2005) \\
\hline Rice hull & $\begin{array}{l}\text { Basic blue } 3 \\
\text { Reactive orange } 16\end{array}$ & $\begin{array}{l}14.68 \mathrm{mg} / \mathrm{g} \\
6.24 \mathrm{mg} / \mathrm{g}\end{array}$ & Ong et al. (2007) \\
\hline Rice husk carbon & Congo red & $\begin{array}{l}10 \text { to } 99 \% \text { (Initial dye concentration } \\
25 \mathrm{ppm} \& \text { adsorbent dose } 0.08 \mathrm{~g} / \mathrm{L} \text { ) }\end{array}$ & Sharma and Janveja (2008) \\
\hline Saw dust & Ethylene blue & $\begin{array}{l}87.7 \mathrm{mg} / \mathrm{g} \text { (natural saw dust). } \\
188.7 \mathrm{mg} / \mathrm{g} \text { (treated saw dust) }\end{array}$ & Gong et al. (2008) \\
\hline Beech wood saw dust & $\begin{array}{l}\text { Direct orange } 26 \\
\text { Acid green } 20 \\
\text { Aid orange } 7\end{array}$ & $\begin{array}{l}2.78 \mathrm{mg} / \mathrm{g} \\
7.81 \mathrm{mg} / \mathrm{g} \\
5.06 \mathrm{mg} / \mathrm{g}\end{array}$ & Izadyar and Rahimi (2007) \\
\hline Activated sludge & Rhodamine-B & $\begin{array}{l}5.121 \mathrm{mg} / \mathrm{g}\left(5^{\circ} \mathrm{C}\right), 4.847 \mathrm{mg} / \mathrm{g} \\
\left(15^{\circ} \mathrm{C}\right), 4.456 \mathrm{mg} / \mathrm{g}\left(25^{\circ} \mathrm{C}\right), \\
3.725 \mathrm{mg} / \mathrm{g}\left(45^{\circ} \mathrm{C}\right)\end{array}$ & Ju et at. (2006) \\
\hline Sewage sludge activated carbons & Reactive dye & $33.5 \mathrm{mg} / \mathrm{g}$ & Reddy et at. (2006) \\
\hline Granular activated sludge & Acid orange 7 & $\begin{array}{l}92 \% \text { (at dye loading rate of } \\
590 \mathrm{mg} / \mathrm{L} \text {.day }\end{array}$ & Mendez-Paz et al. (2005) \\
\hline $\begin{array}{l}\text { Fermentation waste } \\
\text { (Corynebacterium glutamicum) }\end{array}$ & Reactive black 5 & $\begin{array}{l}169.5 \mathrm{mg} / \mathrm{g}\left(20^{\circ} \mathrm{C}\right) \\
185.2 \mathrm{mg} / \mathrm{g}\left(40^{\circ} \mathrm{C}\right)\end{array}$ & Won et al. (2006) \\
\hline Sewage treatment plant sludge & Rhodamine B & $\begin{array}{l}5.121 \mathrm{mg} / \mathrm{g}\left(5^{\circ} \mathrm{C}\right), \\
4.847 \mathrm{mg} / \mathrm{g}\left(15^{\circ} \mathrm{C}\right), \\
4.456 \mathrm{mg} / \mathrm{g}\left(25^{\circ} \mathrm{C}\right), \\
3.725 \mathrm{mg} / \mathrm{g}\left(45^{\circ} \mathrm{C}\right)\end{array}$ & Ju et al. (2006) \\
\hline Water treatment plant sludge & Reactive orange 16 & $47.0 \mathrm{mg} / \mathrm{g}$ & Won et al. (2006a) \\
\hline Sewage treatment plant sludge & Reactive orange 16 & $114.7 \mathrm{mg} / \mathrm{g}$ & Won et al. (2006a) \\
\hline Anaerobic digestion sludge & Reactive orange 16 & $86.8 \mathrm{mg} / \mathrm{g}$ & Won et al. (2006a) \\
\hline Land fill sludge & Reactive orange 16 & $159.0 \mathrm{mg} / \mathrm{g}$ & Won et al. (2006a) \\
\hline Brewery yeast dead cell & Reactive orange 16 & $\begin{array}{l}0.604 \mathrm{mg} / \mathrm{g}(\mathrm{pH} 3), 0.090 \mathrm{mg} / \mathrm{g} \\
(\mathrm{pH} 7), 0.50 \mathrm{mg} / \mathrm{g}(\mathrm{pH} 10)\end{array}$ & Kim et al. (2004) \\
\hline Baker's yeast cells & $\begin{array}{l}\text { Acridine orange } \\
\text { Aniline blue } \\
\text { Malachite green } \\
\text { Safranine O } \\
\text { Crystal violet }\end{array}$ & $\begin{array}{l}82.8 \mathrm{mg} / \mathrm{g} \\
430.2 \mathrm{mg} / \mathrm{g} \\
19.6 \mathrm{mg} / \mathrm{g} \\
90.3 \mathrm{mg} / \mathrm{g} \\
85.9 \mathrm{mg} / \mathrm{g}\end{array}$ & Singh and Rastogi (2004) \\
\hline Fungus & Reactive red 198 & $1.03 \times 10^{-4} \mathrm{~mol} / \mathrm{g}$ & Akar et al. (2009) \\
\hline Fungal biomass (Aspergillus niger) & $\begin{array}{l}\text { Acid blue } 29 \\
\text { Disperse red } 1 \\
\text { Congo red } \\
\text { Basic blue } 9 \\
\end{array}$ & $\begin{array}{l}64.7 \mathrm{mg} / \mathrm{g} \\
0.1 \mathrm{mg} / \mathrm{g} \\
1.1 \mathrm{mg} / \mathrm{g} \\
8.9 \mathrm{mg} / \mathrm{g} \\
\end{array}$ & Fu and Viraghavan (2003) \\
\hline Gulmohor leaves & Methylene blue & $\begin{array}{l}120 \mathrm{mg} / \mathrm{g}(293 \mathrm{~K}), 178 \mathrm{mg} / \mathrm{g}(303 \mathrm{~K}) \\
\text { and } 253 \mathrm{mg} / \mathrm{g}(313 \mathrm{~K})\end{array}$ & Ponnusami et al. (2009) \\
\hline
\end{tabular}

Continuation Table 1 
Continuation Table 1

\begin{tabular}{|c|c|c|c|}
\hline Name of Adsorbent & Dye & Adsorption Capacity & Reference \\
\hline Used tea leaves carbon & $\begin{array}{l}\text { Malachite green } \\
\text { Methylene blue }\end{array}$ & $\begin{array}{l}444.44 \mathrm{mg} / \mathrm{g} \\
454.5 \mathrm{mg} / \mathrm{g}\end{array}$ & Singh and Rastogi (2004) \\
\hline Agave (Americana (L.) leaves fibres & Alpacide yellow & $\begin{array}{l}16.97 \mathrm{mg} / \mathrm{g}\left(20^{\circ} \mathrm{C}\right), 15.79 \mathrm{mg} / \mathrm{g} \\
\left(30^{\circ} \mathrm{C}\right) \text { and } 21.41 \mathrm{mg} / \mathrm{g}\left(50^{\circ} \mathrm{C}\right)\end{array}$ & Hamissa et al. (2008) \\
\hline Pandanus leaves & Congo red & $\begin{array}{l}21.491 \mathrm{mg} / \mathrm{g}\left(30^{\circ} \mathrm{C}\right), 20.267 \mathrm{mg} / \mathrm{g} \\
\left(40^{\circ} \mathrm{C}\right), 20.069 \mathrm{mg} / \mathrm{g}\left(50^{\circ} \mathrm{C}\right), \\
18.928 \mathrm{mg} / \mathrm{g}\left(60^{\circ} \mathrm{C}\right)\end{array}$ & Hema and Arivoli (2007) \\
\hline Pandanus leaves & Malachite green & $\begin{array}{l}9.737 \mathrm{mg} / \mathrm{g}\left(30^{\circ} \mathrm{C}\right), 9.624 \mathrm{mg} / \mathrm{g} \\
\left(40^{\circ} \mathrm{C}\right), 9.633 \mathrm{mg} / \mathrm{g}\left(50^{\circ} \mathrm{C}\right) \\
9.569 \mathrm{mg} / \mathrm{g}\left(60^{\circ} \mathrm{C}\right)\end{array}$ & Hema and Arivoli (2007) \\
\hline Tendu (Diospyros melanoxylon) leaf & Crystal violet & $\begin{array}{l}67.57-22.47 \mathrm{mg} / \mathrm{g} \text { depending on } \\
\text { processing of adsorbent. }\end{array}$ & Nagda and Ghole (2008) \\
\hline Tuberose sticks & Methylene blue & $\begin{array}{l}80 \% \text { (at } \mathrm{pH} 11, \text { adsorbent dose } 1 \mathrm{~g} / \mathrm{L}, \\
40 \mathrm{mg} / \mathrm{L} \text { dye concentration) }\end{array}$ & Habib et al. (2006) \\
\hline Flame tree (Delonix regia) pods & Crystal violet & $16.70 \mathrm{mg} / \mathrm{g}$ & $\begin{array}{l}\text { Ramakrishna and Nagarajan } \\
(2009)\end{array}$ \\
\hline Muntingia calabura Leaves & $\begin{array}{l}\text { Methylene blue } \\
\text { Methylene red } \\
\text { Malachite green }\end{array}$ & $\begin{array}{l}20 \mathrm{mg} / \mathrm{g} \\
58 \mathrm{mg} / \mathrm{g} \\
32 \mathrm{mg} / \mathrm{g}\end{array}$ & Santhi et al. (2009) \\
\hline $\begin{array}{l}\text { Water hyacinths (Eichhornia } \\
\text { crassipes) }\end{array}$ & Acid and reactive dyes & $\begin{array}{l}\text { Higher } \mathrm{N}_{2} \text { percent of hyacinths } \\
\text { showed higher adsorption capacities }\end{array}$ & El-Zawahry and Kamel (2004) \\
\hline Seaweed (Luminaries sp.) & Reactive black 5 & $101.5 \mathrm{mg} / \mathrm{g}$ & Vijayaraghavan and Yun (2008) \\
\hline Sea grass leaf sheaths & Reactive red 228 & $80 \%$ dye removal efficiency at $\mathrm{pH} 5$ & Ncibi et al. (2007) \\
\hline Aquatic plant (Hydrilla verticillata) & Malachite green & $91.97 \mathrm{mg} / \mathrm{g}$ & Rajeshkannan et al. (2010) \\
\hline Teak tree bark & Methyleme blue & $333.33 \mathrm{mg} / \mathrm{g}$ & Patil et al. (2011) \\
\hline Oak saw dust & Methylene blue & $38.46 \mathrm{mg} / \mathrm{g}$ & El-latif et at. (2010) \\
\hline Barley straw & Methylene blue & $27.72 \mathrm{mg} / \mathrm{g}$ & Abdualhamid and Asil (2011) \\
\hline Wheat straw & Methylene blue & $17.54 \mathrm{mg} / \mathrm{g}$ & Abdualhamid and Asil (2011) \\
\hline Oat straw & Methylene blue & $8.34 \mathrm{mg} / \mathrm{g}$ & Abdualhamid and Asil (2011) \\
\hline Papaya seeds & Methylene blue & $\begin{array}{l}250.0 \mathrm{mg} / \mathrm{g} \text { (esterified adsorbent) } \\
200 \mathrm{mg} / \mathrm{g} \text { (natural adsorbent) }\end{array}$ & Nashuha et al. (2011) \\
\hline Annona squamosa seeds & $\begin{array}{l}\text { Methylene blue } \\
\text { Methylene red } \\
\text { Malachite green }\end{array}$ & $\begin{array}{l}8.52 \mathrm{mg} / \mathrm{g} \\
40.48 \mathrm{mg} / \mathrm{g} \\
25.91 \mathrm{mg} / \mathrm{g}\end{array}$ & Santhi et al. (2010) \\
\hline Hen feathers & Tartrazine (azo dye) & $\begin{array}{l}47 \%\left(30^{\circ} \mathrm{C}\right), 52 \%\left(40^{\circ} \mathrm{C}\right), 55 \% \\
\left(50{ }^{\circ} \mathrm{C}\right)\end{array}$ & Mittal et al. (2007) \\
\hline Chitosan & FD\&C Red n ${ }^{\circ} 40$ dye & $\begin{array}{l}1065.8 \mu \mathrm{mol} / \mathrm{g}(308 \mathrm{~K}), \\
1061.4 \mu \mathrm{mol} / \mathrm{g}(318 \mathrm{~K}), 800.8 \mu \mathrm{mol} / \mathrm{g} \\
(328 \mathrm{~K}), 508.5 \mu \mathrm{mol} / \mathrm{g}(338 \mathrm{~K})\end{array}$ & Piccin et al. (2011) \\
\hline Cotton fibres & $\begin{array}{l}\text { Reactive red } 120 \\
\text { Reactive black } 5\end{array}$ & $\begin{array}{l}11.63 \mathrm{mg} / \mathrm{g} \\
6.22 \mathrm{mg} / \mathrm{g}\end{array}$ & Gamal et al. (2010) \\
\hline Commercial activated carbon & $\begin{array}{l}\text { Turquoise blue QG } \\
\text { reactive bye }\end{array}$ & $140.14 \mathrm{mg} / \mathrm{g}$ & Schimmel et al. (2010) \\
\hline
\end{tabular}

\section{CONCLUSIONS}

Agricultural residues are abundantly available. For using as adsorbents, the agricultural residues are required to be properly treated. The treatments employed by researchers involve physical and chemical processes such as washing, drying, size reduction, burning to produce ash, burning in the absence of oxygen to obtain char, carbonizing and specific treatment to effect chemical modifications. This literature review shows that it is possible to develop agricultural residues for use as adsorbents in colour removal from effluents. The adsorption capacity data reported in the literature indicate that dye removal through the use of agricultural residue is feasible. Although intensive studies have been undertaken on the lab scale with different processes parameters, there is a need to explore the adsorption potential of the agriculture residues through pilot plant studies to establish the treatment process at commercial level.

\section{REFERENCES}

Abdullah, A. G. L., Salleh, M. A. M., Mazlina, M. K. S., Noor, M. J. M. M., Osman, M. R., Wagiran, R., Sobri, S., Azo dye removal by adsorption using waste biomass: Sugarcane bagasse. Int. J. Eng. 
Technol., 2(1), 8-13 (2005).

Abdualhamid, S. A. and Asil, A. A., The effect of soaking process of agricultural wastes on the adsorption of Methylene blue dye. International Food Research J., 18(3), 977-981 (2011).

Akar, S. T., Akar, T. and Cabuk, A., Decolorization of a textile dye Reactive red 198 (RR 198), by $A s$ pergillus parasiticus fungal biosorbent. Brazilian Journal of Chemical Engineering, 26(02), 399405 (2009).

Allen, S. J. and Koumanova, B., Decolourisation of water/wastewater using adsorption (Review). J. University of Chemical Technology and Metallurgy, 40(3), 175-192 (2005).

Amin, K. N., Removal of reactive dye from aqueous solution by adsorption onto activated carbons prepared from sugarcane bagasse pith. Desalination, 223, 152-161 (2008).

Ansari, R., Khan, A. M. and Mosayebzadeh, Z., Application of unripe grape juice waste as an efficient low cost biosorbent for dye removal. Annals of Biological Research, 2(5), 323-328 (2011).

Ashoka, H. S. and Inamdar, S. S., Adsorption removal of Methyl red from aqueous solution with treated sugarcane bagasse and activated carbon- a comparative study. Global J. Environ. Res., 4(3), 175-182 (2010).

Azhar, S. S., Liew, A. G., Suhardy, D., Hafz, K. F. and Hatm, H. D. F., Dye removal from aqueous solution by using adsorbent on treated sugarcane bagasse. American J. Appl. Sci., 2(11), 1499-1503 (2005).

Babu, C. S., Chakrapani, C. C. and Rao, K. S., Equilibrium and kinetic studies of reactive red 2 dye adsorption onto prepared activated carbons. J. Chem. Pharm. Res., 3(1), 428-439 (2011).

El-Zawahry, M. M. and Kamel, M. M., Removal of azo and anthraquinone dyes from aqueous solutions by Eichhornia crassipes. Water Research, 38, 2967-2972 (2004).

El-Latif, M. M. A., Ibrahim, A. M. and El-Kady, M. F., Adsorption equilibrium, kinetics and thermodynamics of Methylene blue from aqueous solutions using biopolymer oak sawdust composite. J. American Science, 6(6), 267-283 (2011).

$\mathrm{Fu}$, Y. and Viraraghavan, T., Column studies for biosorption of dyes from aqueous solutions on immobilised Aspergillus niger fungal biomass. Water SA, 29, 465-472 (2003).

Gamal, A. M., Farha, S. A. A., Sallam, H. B., Mahmoud, G. E. A. and Ismil, L. F. M., Kinetic study and equilibrium isotherm analysis of reactive dyes adsorption onto cotton fiber. Nature and Science, 8(11), 95-110 (2010).
Gong, R., Liu, X., Feng, M., Liang, J., Cal, W. and Li, N., Comparative study of Methylene blue sorbed on crude and monosodium glutamate functionalized sawdust. J. Health and Sci., 54(6), 623628 (2008).

Habib, A., Hassa, Z., Rahman, A. S. M. S. and Alam, A. S. M., Tuberose sticks as an adsorbent in the removal of Methylene blue from aqueous solution. Pak J. Environ. Chem., 7(2), 112-115 (2006).

Hamissa, A. M., Ncibi, M. C., Mahjoub and Seffen, M., Biosorption of metal dye from aqueous solution onto Agave americana (L.) leaves. Int. J. Environ. Sci. Tech., 5(4), 501-508 (2008).

Hema, M. and Arivoli, S., Comparative study on the adsorption kinetics and thermodynamics of dye onto acid activated low cost adsorbent. International J. Physical Science, 2(1), 10-17 (2007).

Ho, Y. S., Chiu, W. T. and Wang, C. C., Regression analysis for the sorption of basic dyes on sugarcane dust. Bioresource Technology, 96, 285-1291 (2005).

Izadyar, S. and Rahimi, M., Use of beach wood saw dust for adsorption of textile dyes. Pakistan J. Biological Science, 10(2), 287-293 (2007).

Jaikumar, V. and Ramamurthi, V., Adsorption of acid yellow by spent brewery grain in a batch system: Equilibrium and kinetic modeling. International J. of Biology, 1(1), 21-29 (2009).

Jayarajan, M., Arunachalam R. and Annaduria, G., Agricultural wastes of jackfruit peel nano-porous adsorbent for removal of Rhodamine dye. Asian J. Applied Science, 43, 263-270 (2011).

Ju, D. J., Byun, I. G., Lee, C. H., An, G.H., Park, T. J., Biosorption characteristics of reactive dye onto dried activated sludge. Water Practice \& Technology, 1(3), (2006).

Khandelwal, S. K. and Gaikwad, R. W., Removal of dyes from dye effluent using sugarcane bagasse ash as an adsorbent. International J. Chemical Engineering and Applications, 2(3), 309-317 (2011).

Kaushik, N., Kaushik, C. P., Tateja, R. and Sharma, J. K., Studies on adsorption of Triazine dyes by natural and chemical modified agro waste materials. Rasayan J. Chem., 1(4), 819-827 (2008).

Kim, T. Y., Baek, S. J., Rho, S. G., Kim, S. J. and Cho, S. Y., Adsorption characteristics of reactive dye onto biosorbent. Theories and Application of Chem. Eng., 10(2), 1402-1404 (2004).

Ladhe, U. V., Wankhede, S. K., Patil, V. T. and Patil, P. R., Adsorption of Erichrome black $\mathrm{T}$ from aqueous solutions on activated carbon prepared from mosambi peel. J. Applied Science in Environmental Sanitation, 6(2), 149-154 (2011). 
Mafra, M. R., Igarashi-Mafra, L., Zuim, D. R., Vasques, E. C. and Ferreira, M. A., Adsorption of Remazol brilliant blue on an orange peel adsorbent. Brazilian J. Chemical Engineering, 30(3), 657-665 (2013).

Mahesh, S., Kumar, V. G. and Agrawal, P., Studies on the utility of plant cellulose waste for the bioadsorption of Crystal violet dye. J. Environment Biology, 31, 277-280 (2010).

Mendez-Paz, D., Omil, F. and Lema, J. M., Anaerobic treatment of azo dye Acid orange 7 under fedbatch and continuous conditions. Water Research, 39, 771-778 (2005).

Mittal, A., Kurup, L. and Mittal, J., Freundlich and Langmuir adsorption isotherms and kinetics for the removal of Tartrazine from aqueous solutions using hen feathers. J. Hazardous Materials, 146, 243-248 (2007).

Nakamura, T., Tokimoto, T., Tamura, T., Kawasaki, N. and Tanada, S., Decolourisation of acid dye by charcoal from coffee grounds. J. Health Science, 49(6), 520-523 (2003).

Nanda, G. K. and Ghole, V. S., Utilisation of lignocellulosic waste from bidi industry for removal of dye from aqueous solution. Int. J. of Environmental Research, 2(4), 385-390 (2008).

Nasuha, N., Zurainan, H. Z., Maarof, H. I., Zubir, N. A. and Amri, N., Effect of cationic and anionic dye adsorption from aqueous solution by using chemically modified papaya seed. International Conference on Environment Science and Engineering, IPCBEE, Singapore, 8, 50-54 (2011).

Ncibi, M. C., Mahjoub, B. and Seffen, M., Adsorptive removal of textile reactive dye using Posidonia oceanica (L.) fibrous biomass. Int. J. Environ. Sci. Tech, 4(4), 433-440 (2007).

Ong, S. T., Keng, P. S., Voon, M. S., Lee, S. L. and Hung, Y. T., Sorption of basic dye from aqueous solution by durian peel (Durio zibethinus murray). World Applied Science J., 9(3), 245-249 (2010).

Ong, S. T., Lee, C. K. and Zainal, Z., Removal of basic reactive dyes using Ethylenediamine modified rice hull. Bioresource Technology, 98, 27922799 (2007).

Parvathi, C. and Maruthavana, T., Adsorptive removal of Megeta MB cold brand reactive dye by modified activated carbons derived from agricultural waste. Indian J. Science and Technology, 3(4), 408-410 (2010).

Patil, S., Renukdas, S. and Patel, N., Removal of Methylene blue, a basic dye from aqueous solutions by adsorption using teak tree (Tectona grandis) bark powder. International J. Environmental Sciences, 1(5), 711-726 (2011).
Piccin, J. S., Dotto, G. L. and Pinto, L. A. A., Adsorption isotherms and thermochemical data of FD\&C Red $n^{\circ} 40$ binding by Chitosan. Brazilian J. Chemical Engineering, 28(2), 295-304 (2011).

Ponnusami, V., Aravindhan, R., Karthiraj, N., Ramadoss, G. and Srivastawa, S. N., Adsorption of Ethylene blue onto gulmohar plant leaf powder: Equilibrium, kinetic and thermodynamic analysis. J. Environmental Protection Science, 3, 1-10 (2009).

Prasad, R. N., Viswanathan, S., Devi J. R., Rajkumar, J. and Parthasarathy, N., Kinetics and equilibrium studies on biosorption of CBB by coir pith. American-Eurasian J. Scientific Research, 3(2), 123-127 (2008).

Purai, A. and Rattan, V. K., Removal of Basic green 4 from wastewater by adsorption on biomass ash and activated carbon. Indian Chemical Engineer, 51(4), 287-299 (2009).

Rachakornkij, M., Ruangchuay, S. and Teachakulwiroj, S., Removal of reactive dyes from aqueous solution using bagasse fly ash. Songklanakarin J. Science and Technology, 26 (2004).

Raghuvanshi, S. P., Singh, R. and Kaushik, C. P., Kinetics study of methyene blue bye bioadsorption on baggase. Applied Ecology and Environmental Research., 2(2), 35-43, (2004).

Rajavel, G., Anathanarayanan, C., Prabhakar, L. D. and Palanivel, C., Removal of Dark green PLS dye from textile industrial waste through low cost carbons. Indian J. Environ. Health, 45(3), 195-202 (2003).

Rajeshkannan, R., Rajasimman, M. and Rajamohan, N., Removal of Malachite green from aqueous solution using Hydrilla verticillata - optimization, equilibrium and kinetic studies. International $\mathrm{J}$. Civil and Environmental Engineering, 2(4), 222229 (2010).

Ramakrishnan, M. and Nagarajan, S., Utilization of waste biomass for the removal of basic dyes from water. World Applied Science J., 5 (Special Issue for Environment), 114-121 (2009).

Reddy, S. S. and Kotaiah, B., Reddy, N. S. P. and Velo, M., Removal of composite reactive dye from dyeing unit effluents using sewage sludge derived activated carbon. Turkish J. Engineering and Environmental Science, 30, 367-377 (2006).

Rusly, S. M. and Ibrahim, S., Adsorption of textile reactive dye by palm shell activated carbon, Response Surface Methodology. World Academy of Science, Engineering and Technology, 67, 892895 (2010).

Santhi, T., Manonmani, S. and Ravi, S., Uptake of cationic dyes from aqueous solution by biosorption onto granular Muntingia calabura. E-J. Chemistry, 6(3), 737-742 (2009). 
Schimmel, D., Fagnani, K. C., Santos, J. B., Barros, M. A. S. D. and Silva, E., Adsorption of turquoise blue QG reactive bye commercial activated carbon in batch reactor: Kinetic and equilibrium studies. Brazilian J. Chemical Engineering, 27(2), 289-298 (2010).

Sharma, J. and Janveja, B., A study on removal of Congo red dye from the effluent of textile industry using rice husk activated by steam. Rasayan J. Chemistry, 1(4), 653-958 (2008).

Singh, D. K. and Rastogi, K., Adsorptive removal of basic dyes from aqueous phase onto activated carbon of used tea leaves: A kinetic and thermodynamic study. J. Environmental Science and Engineering, 46(4), 293-302 (2004).

Sivakumar, P. and Palanisamy, N., Mechanistic study of dye adsorption on to a novel non-conventional low-cost adsorbent. Library Advances in Applied Science Research, 1(1), 58-65 (2010).

Sreelatha, G. and Padmaja, P., Study of removal of cationic dyes using palm shell powder as adsorbent. J. Environmental Protection Science, 2, 6371 (2008).

Tahir, H., Hammed, U., Jahanzeb, G. and Sultan, M., Removal of fast green dye from and aqueous solution using Azadirachta leaf powder as low cost adsorbent. Asian Technology of Biotechnology, 7(21), 2906-2911 (2008).

Theivarasu, C. and Mylsamy, S., Equilibrium and kinetic adsorption studies of Rhodmine-B from aqueous solutions using cocoa (Theobroma cacao) shell as a new adsorbent. International $\mathrm{J}$. Engineering, Science and Technology, 2(11), 62846292 (2010).

USEPA, Profile of Textile Industry (Publication No. EPA/310-R-97-009). U.S. Environmental Protection Agency, Washington, 40-41 (1997).

Velmurugan, P., Kumar V. R. and Dhinakaran, G., Dye removal from aqueous solution using low cost adsorbent. Int. J. Environmental Science, 1(7), 1492-1503 (2011).

Vijayaraghavan, K. and Yun, Y. S., Biosorption of C.I. Reactive Black 5 from aqueous solution using acid-treated biomass of brown seaweed laminaria sp. Dyes and Pigments, 76, 726-732 (2008).

Won, S. W., Kim, H. J., Choi, S. H., Chung, B. W., Kim, K. J. and Yun, Y. S., Performance, kinetics and equilibrium in biosorption of anionic dye Reactive black 5 by the waste biomass of Corynebacterium glutamicum as a low-cost biosorbent. Chemical Engineering Journal, 121, 37-43 (2006).

Won, S. W., Choi, S. B. and Yun, Y. S., Performance and mechanism in binding of Reactive orange 16 to various types of sludge. Biochemical Engineering Journal, 28, 208-214 (2006a).

Wong, S. Y., Tan, Y. P., Abdullah, A. H. and Ong, S. T., The removal of basic and reactive dyes using quartenised sugar cane bagasse. J. Physical Science, 20(1), 59-74 (2009).

Zollinger, H., Colour Chemistry. Second Edition, Weinheim, New York, 8-9 (1991). 